UNITED STATES DEPARTMENT OF THE INTERIOR

J. A. Krug, Secretary

GEOLOGICAL SURVEY

W. E. Wrather, Director

Bulletin 955-B

\title{
STRUCTURAL CONTROL OF THE GOLD DEPOSITS \\ OF THE CRIPPLE CREEK DISTRICT \\ TELLER COUNTY, COLORADO
}

\author{
BY \\ A. H. KOSCHMANN \\ Prepared in cooperation with the \\ COLORADO GEOLOGICAL SURVEY BOARD and the \\ COLORADO METAL MINING FUND
}

Contributions to economic geology, 1947

(Pages 19-58)

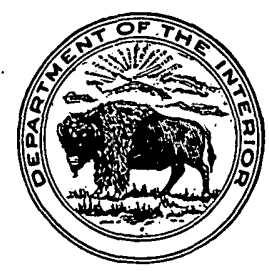

1849-A CENTURY OF CONSERVATION-1949

UNITED STATES

GOVERNMENT PRINTING OFFICE

WASHINGTON : 1949

For sale by the Superintendent of Documents, U. S. Government Printing Office, Washington 25, D. C. Price $\$ 1.25$ 


\section{CONTENTS}

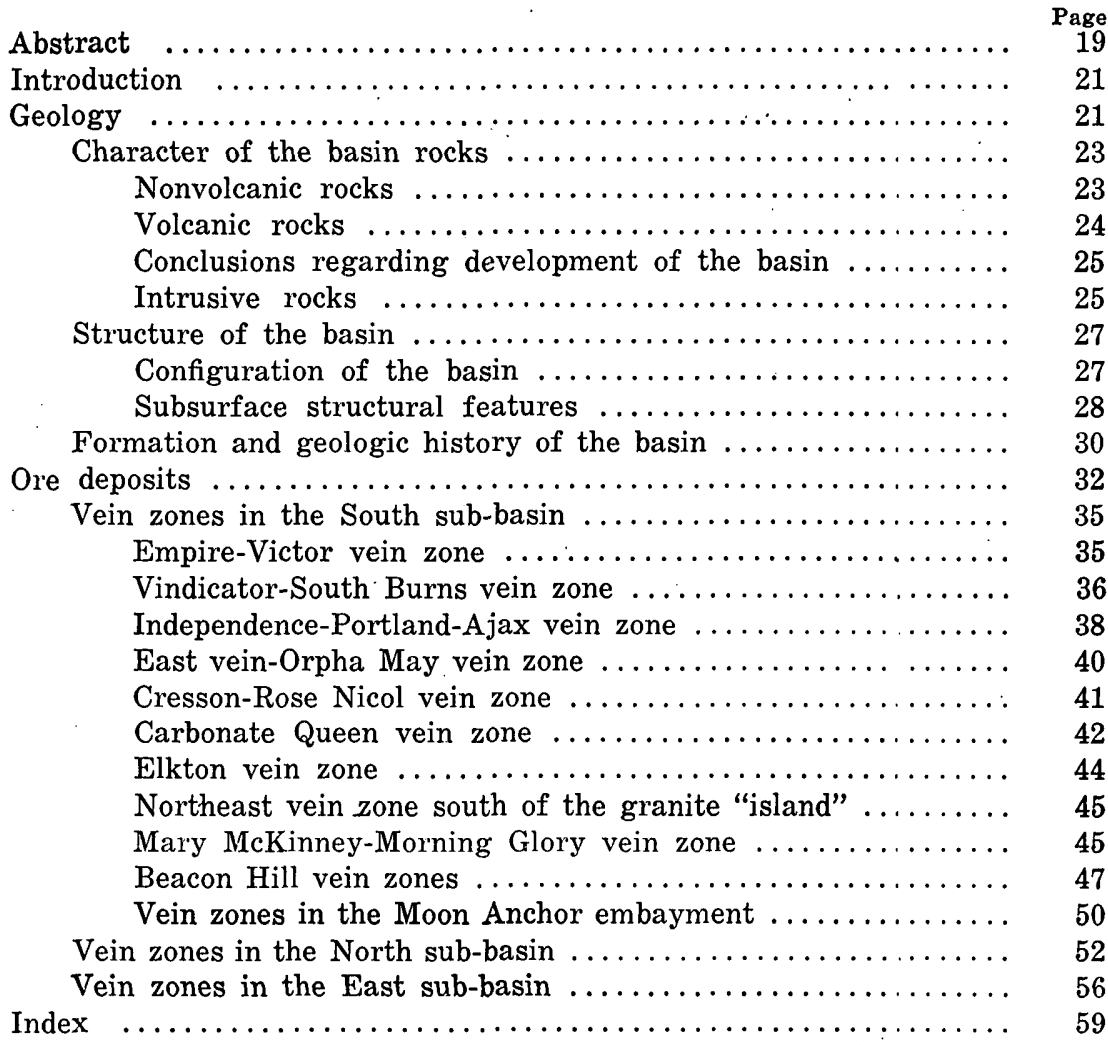

\section{ILLUSTRATIONS}

Plate 3. Geologic map of Cripple Creek mining district and area

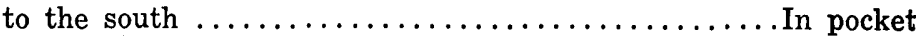

4. Map of Cripple Creek basin showing the subsurface breccia-granite contact, arrangement of veins, and the location of the principal shafts and tunnels...... In pocket 



\title{
STRUCTURAL CONTROL OF THE GOLD DEPOSITS OF THE CRIPPLE CREEK DISTRICT, TELLER COUNTY, GOLORADO
}

\author{
By A. H. KoschmanN
}

\begin{abstract}
ABSTRAC'T
Most of the gold deposits of the Cripple Creek district occur within or at the margin of a mass of fragmental rocks of volcanic and nonvolcanic origin, collectively called "breccia," of Miocene age. The breccia occupies a steepwalled basin or caldera in pre-Cambrian granite, gneiss, and schist.

Petrologic, structural, and fossil evidence indicates that the pit or basin occupied by the main mass of breccia was formed by intermittent subsidence along steeply dipping faults and is not a volcanic neck formed by a volcanic explosion, although igneous activity that occurred during and after subsidence tends to obscure the true relations. Development of the basin took place in several stages; the earliest predates the igneous activity that furnished the volcanic material of the breccia, and the latest is marked by the formation of the gold deposits.

Origin of the basin by intermittent subsidence is evidenced especially by the wide range in structure, texture, and composition of the fragmental rocks. The nonvolcanic rocks, locally present throughout the basin, range from coarse conglomerate to arkose and mudstone, with partings of shale and laminae of limestone.

The volcanic fragmental rocks form the bulk of the rocks filling the basin. They range from fine-grained tuff to coarse breccia. Most of them are wellsorted, and some are well-bedded. Even at great depth the breccia and tuff show depositional features, indicating that the volcanic detritus was reworked and laid down mainly under water. The persistence of such water-laid volcanic detritus to the greatest depths reached by mining- 3,350 feet in the Portland mine-indicates that the basin subsided slowly and that accumulation kept pace with subsidence. The accumulation of so great a thickness of stratified rocks at such great depth in a steep-walled basin of pre-Cambrian rocks indicates that these rocks owe their present position to subsidence through faulting. Fault breccia, gouge, and slickensides, direct evidence of fault movement, are found at many places along the contact between the breccia and the pre-Cambrian rocks.

The fragmental rocks in the basin were successively intruded by dikes and irregular masses of latite-phonolite, syenite, phonolite, and alkaline basaltic rocks.

The rim of the basin is rudely elliptical in general outline, but it is irregular in detail. Its longer axis strikes northwest, and both short and long stretches of the rim are approximately parallel to this northwestwardtrending axis. The irregularities are significant because of their structural relation to the vein zones of the district. The marked parallelism of prevailing stretches of the rim implies that the outline of the basin was con-
\end{abstract}


trolled by a preexisting fissure system along which subsidence of the breccia mass took place and along which igneous processes were active.

The subsurface structural features and configuration of the basin can be deciphered only in a general way. The basin walls are irregular, but in general they slope steeply toward the center of the basin. They overhang in places, however, notably along the southwest wall, and in a few places the average slope is as low as $46^{\circ}$. During subsidence the floor and walls of the basin were faulted, and some of the fault blocks subsided to great depths. Available data show that the main basin is composite in structure and comprises three minor basins or sub-basins separated by buried granite ridges. Mine workings have also exposed three buried granite spurs that project into the basin beneath the breccia. These trend northwestward, essentially parallel with the major axis of the basin. Their steep slopes and relations to the basin indicate that they are horsts.

The ore deposits of the Cripple Creek district occur chiefly as veins within the fragmental rocks and igneous intrusive bodies in the basin, but a few veins extend into the adjacent pre-Cambrian rocks. One of the outstanding features of the vein fissures is their arrangement in relatively long narrow zones that are separated one from another by broad relatively barren zones. The main zones of fissure veins are parallel to the local primary structural features of the basin, and they are thus genetically related. Some of the vein zones coincide with or are parallel to major structural features in the floor of the basin, such as buried granite ridges (horsts), whereas others are related to structural features along the walls of the basin and accord in distribution with many of the sharp bends along the breccia-granite contact. Among these some coincide with or are parallel to those segments of the contact that trend essentially normal to the general local trend of the contact, such as the northward-trending segments of contact along the generally eastward-trending south wall of the basin; others lie opposite such bends or breaks and appear to be shear zones along the extension of the fissures along which the basin formed.

The close structural relation between many of the vein fissure zones and the local structural features of the walls and floor of the basin furnishes a guide for future exploration. Irregularities along the granite-breccia contact marking analogous structural features along the basin wall in unexplored or inadequately explored areas should be sought and the neighboring rocks explored. The genetic relations between vein zones and structural

features of the basin imply further that those fissure zones that are related to subsurface structural features, and hence are upward extensions of the controlling primary fissures in the floor of the basin, will persist down the din to a connection with the primary fissure. These fissures in the hasin floor were presumably the trunk channels that tapped the igneous reservoirs and were the channels along which the ore solutions rose. Although most of the major zones of vein fissures may be deep-seated, veins along them in general become fewer and more restricted in distribution with depth, and the vein zones thus become increasingly narrow. Accordingly, ore shoots will become fewer with depth and will converge toward the relatively few deep sources of the ore solutions.

The vein zones are described briefly and their relation to structural features of the walls and floor of the basin is outlined. This structural analysis leads to recognition of certain undeveloped areas in the district whose favorable structural setting recommends them for exploration, and it leads also 
to recognition of certain places along the vein zones where deep exploration seems justified.

\section{INTRODUCTION}

The gold deposits of the Cripple Creek district were discovered in 1891, and to the end of 1946 the district had produced a total of 18,572,959 fine ounces of gold and 2,089,367 fine ounces of silver. Output reached its peak in 1900 , when 878,067 ounces of gold, valued at $\$ 18,149,645$, was mined. Thereafter output fluctuated but in general declined until 1932, when the district produced only 109,346 ounces of gold and 7,656 ounces of silver. Interest in the district was revived by the depression of 1930-33, especially late in 1933 and early in 1934 when the price of gold was increased from $\$ 20.67$ to $\$ 35$ an ounce, and many mines that had been inaccessible for many years were then reopened. In 1941 interest in the camp was further stimulated by the driving of the Carlton deep-level drainage tunnel (altitude of portal, 6,893 feet), which made available reserves that, because of pumping costs, could not be economically prospected and mined previously. Early in 1942 Government regulations, ${ }^{1}$ labor and material shortages, and economic factors related to World War II forced many mines to close, and production declined markedly during the war years. The known ore reserves, however, together with the indicated and inferred reserves, are large, and the chances of substantial recovery are favorable.

The object of this paper is to analyze the factors that controlled the localization of the known vein fissures and from such an analysis to point out favorable areas for prospecting in unexplored or inadequately explored parts of the district.

\section{GEOLOGY}

A detailed description of the geology of the Cripple Creek district has been presented in several comprehensive reports, and only a brief outline is attempted here.

The Cripple Creek district lies on a truncated domelike flexure formed during the Laramide revolution ${ }^{2}$ at the southwest end of the Front Range. The range consists chiefly of pre-Cambrian granite, gneiss, and schist, but isolated small infolded and infaulted remnants of Paleozoic and Mesozoic sedimentary rocks flank it on the west. Locally, on a few hills in the southwestern part of the area shown on plate 3, the pre-Cambrian rocks are

\footnotetext{
1 Needham, C. E., Gold and silver: Minerals Yearbook, 1942, pp. 80-84, 1943.

2 Loughlin, G. F., and Koschmann, A. H., Geology and ore deposits of the Cripple Creek district, Colorado: Colorado Sci. Soc. Proc., vol. 13, no. 6, pp. 233-235, 1935.
} 
capped by vólcanic and sedimentary rocks of early Tertiary age. These volcanic rocks include rhyolite and andesite, and the sedimentary rocks include grit, sandstone, and arkose.

Most of the gold deposits of the district occur in a mass of nonvolcanic and volcanic fragmental rocks intruded by dikes and irregular masses of alkaline igneous rocks, which occupy a steepwalled basin in the pre-Cambrian rocks. The early detailed geologic investigations of the Cripple Creek district, first made by Cross and Penrose, ${ }^{3}$ and 10 years later by Lindgren and Ransome, ${ }^{4}$ yielded the classic picture that the basin is the site of a volcanic neck and was formed by explosive eruptions. Later work by Loughlin and Koschmann ${ }^{5}$ modified this picture to that of a composite crater that separated at depth into roots or subcraters that had formed at favorable places along intersecting fissure systems in the pre-Cambrian rocks.

In 1934 and 1935 the presence of much well-bedded sandstone, shale, and conglomerate, derived almost, if not wholly, from preCambrian rocks, was disclosed by the newer mine workings in the eastern part of the district. As these beds were found as much as 1,000 feet below the surface and not far from the preCambrian wall rocks, the suggestion was made ${ }^{6}$ that the floor of the basin may have subsided after the earliest stage of explosive activity and that sedimentary material accumulated on the floor, to be covered later by breccia and tuffs produced by renewed volcanic activity.

Field studies since 1935 have shown that well-bedded and sorted rocks, of both nonvolcanic and volcanic origin, were of very appreciable vertical and horizontal extent. As a result of this evidence it has been concluded ${ }^{7}$ that the main mass of breccia occupies a pit or basin, which owes its origin to intermittent subsidence along vertical or steeply dipping faults and is not a product of violent volcanic eruptions, and that as the basin intermittently subsided it was gradually filled first with nonvolcanic sediment and later with volcanic breccia 3,000 feet and more thick derived from local fissure eruptions.

The basin is composite in structure and was formed by subsidence along faults initiated along dominant fissures of the re-

\footnotetext{
${ }^{3}$ Cross, Whitman, and Penrose, R. A. F., Jr., The geology and mining industries of the Cripple Creek district, Colo.: U. S. Geol. Survey 16th Ann. Rept., pt. 2, pp. 1-209, 1895.

4 Lindgren, Waldemar, and Ransome, F. L., Geology and gold deposits of the Cripple Creek district, Colo.: U. S. Geol. Survey Prof. Paper 54, 1906.

s Loughlin, G. F., and Koschmann, A. H., op. cit., pp. 219-220, 290-293, fig. 10.

- Loughlin, G. F., and Koschmann, A. H., op. cit., p. 247, 1935.

7 Koschmann, A. H., New light on the geology of the Cripple Creek district, Colorado, and its practical significance, pp. 3-13, Denver, Colo., Colorado Mining Assoc., January 1941.
} 
gion that had probably resulted from the Laramide deformation. The development of the basin took place in several stages, the earliest of which predated the igneous activity that furnished most of the fragmental material of the breccia mass; the latest stage was approximately contemporaneous with the formation of the gold deposits. Subsidence culminated before the intrusion of the igneous rocks, but repeated differential movements produced shear zones in the breccia and in adjacent pre-Cambrian rocks, which were followed by the igneous intrusions and later by the ore solutions. Only minor movements followed vein deposition, and they produced faults of relatively small displacement within the district.

\section{CHARACTER OF THE BASIN ROCKS}

The Cripple Creek basin is filled with consolidated fragmental rocks of nonvolcanic as well as volcanic origin, collectively referred to as breccia, which are intruded by dikes and irregular masses of alkaline rocks. In its south-central part the mass of breccia includes a small pipe of basaltic breccia known as the "Cresson blowout." It has been exposed to a depth of more than 2,000 feet and separates at depth into two roots or pipes. ${ }^{8}$

\section{NONVOLCANIC ROCKS}

The nonvolcanic fragmental rocks range from coarse conglomerate and rubble composed of detritus of the adjacent preCambrian rocks to arkose and mudstone with shale partings and laminae of limestone, in all of which volcanic rock fragments are absent. Where the stratigraphic section is most complete a thick series of nonvolcanic fragmental rocks lies stratigraphically below the volcanic breccia; locally such rocks are also interbedded with strata of volcanic breccia. In the eastern part of the basin, referred to as the East sub-basin (see p. 29), where the stratigraphic and genetic relations of the nonvolcanic rocks are best revealed, volcanic breccia is underlain by 200 feet of arkose and 400 feet of conglomerate with channel deposits of arkose and partings of shale. ${ }^{9}$. Interbedded with the arkose are shale partings, in which fossil leaves were found in the Cameron mine, ${ }^{10}$ and some lenses of conglomerate and laminae of limestone. The upper part of the arkose contains increasing amounts of volcanic

\footnotetext{
s Loughlin, G. F., Ore at deep levels in the Cripple Creek district, Colo.: Am. Inst. Min. Met. Eng. Tech. Paper 13, pp. 5-7, 1927. Loughlin, G. F., and Koschmann, A. H., op. cit., pp. 252-261.

o Koschmann, A. H., op. cit., pp. 6-9.

${ }^{10}$ Loughlin, G. F., and Koschmann, A. H., op. cit., p. 246.
} 
debris and thus grades into the overlying series of bedded volcanic fragmental rocks, interbedded with which are layers of nonvolcanic rocks-chiefly arkose and mudstone. In the School Section mine this interbedded series of rocks has been intricately folded and faulted on a small scale and is unconformably overlain by a coarse phonolite breccia, which contains boulders 6 feet or more in diameter.

Although the floor of the basin has not been exposed in mine workings, the absence of admixed volcanic detritus in these basal nonvolcanic rocks and their stratigraphic position below the volcanic breccia are significant in showing that the sub-basin could not have been blown out, to be filled later with detritus washed back in. If the basin had been blown out by a violent eruption, agglomerate would have partly filled the basin, forming its floor, and would have blanketed the surrounding pre-Cambrian country rocks. Such a mass of agglomerate in the basin, together with that washed back in, would have formed a basal formation of volcanic breccia, and the upper portion of the rock section would consist of a mixture of volcanic and pre-Cambrian rock and mineral fragments.

Nonvolcanic fragmental rocks-conglomerate, rubble, arkose, and mudstone-are locally present in other parts of the Cripple Creek basin ${ }^{11}$ and imply the same general structure and sequence of events that are clearly represented in the East sub-basin.

\section{VOLCANIC ROCKS}

The typical volcanic fragmental rocks are tuffs and breccias consisting of fragments of phonolite and latite-phonolite. Small fragments of granite, gneiss, and schist are scattered throughout the breccia, and locally along the margin of the basin the breccia grades into rubble, conglomerate, or mudstone consisting almost wholly of rock and mineral fragments derived from the preCambrian rocks. The breccia is gray to red where unaltered, but marked hydrothermal alteration has bleached much of it nearly white, and over wide areas it has been partly replaced and firmly cemented by secondary albite. The bleached breccia is considerably impregnated with small crystals of pyrite.

Most of the volcanic breccia is finer-grained than typical volcanic agglomerate and is more properly called tuff-breccia and tuff. It ranges from a fine-grained tuff in which the fragments are a quarter of an inch and less in diameter to a breccia in which the fragments range from a quarter of an inch to 2 inches in dia-

${ }^{11}$ Koschmann, A. H., op. cit., pp. 9-10, 12-13. 
meter. Agglomerate, which normally consists of unsorted volcanic debris in which boulders are mingled with fine fragments, is found locally but pinches out within short distances. It forms ony a small part of the volcanic fragmental rock, probably less than 5 percent.

Most of the breccia is well-sorted, and much of it also is wellbedded; it represents volcanic detritus that has been reworked and laid down mainly under water. Some of the breccia and tuff now found at great depth also show features characteristic of shallow water and subaerial deposition, such as mud cracks, raindrop impressions, cross bedding, fossil footprints of birds, and unconformities. Sorted and well-bedded breccia, showing features of shallow water and subaerial deposition, has a wide horizontal and vertical distribution in the basin ${ }^{12}$ and shows that the basin subsided intermittently. Subsidence apparently kept pace with accumulation, and deposits recognizable as having been deposited at the surface became buried locally to the greatest depths reached by mining-at least 3,350 feet in the Portland mine.

\section{CONCLUSIONS REGARDING DEVELOPMENT OF THE BASIN}

The wide range in composition of the fragmental rocks that fill the Cripple Creek basin, and the wide distribution, both horizontally and vertically, of fine-grained, well-sorted, and well-bedded breccia showing many features of shallow-water or subaerial deposition have led to the following conclusions:13 (1) The fragmental rocks for the most part are not direct products of volcanic eruptions but represent debris of volcanic and pre-Cambrian rocks that has been waterlaid in a shallow basin; (2) the nonvolcanic sediments, as well as the great thickness of well-bedded tuffs and breccias, show by their present deep-seated position that the basin has resulted from intermittent subsidence and is not an explosion crater; and (3) the basal stratigraphic position of the nonvolcanic fragmental rocks implies that the early stages of development of the basin preceded volcanic eruption.

\section{INTRUSIVE ROCKS}

The intrusive rocks in the breccia, which consist of dikes, sills, and small plugs or necks, include, in the order of intrusion, latitephonolite, syenite, phonolite, and alkaline basaltic rocks (basic or lamprophyric rocks).

The latite-phonolite is a gray to reddish-gray porphyritic rock, with distinct white phenocrysts of plagioclase embedded in a

${ }^{12}$ Koschmann, A. H., op. cit., pp. 5-13. 
dense groundmass. It forms dikes and sill-like masses, some of which may be buried flows, ${ }^{14}$ and irregular plugs. The plugs and sill-like masses are extensively exposed at the surface in the central part of the district. (See pl. 3)

Syenite forms several small irregular stocks and a large number of dikes, all within the mass of breccia. The largest stock crops out in two small masses between the Vindicator and Last Dollar mines, but underground it extends essentially continuously from the Vindicator to the Rose Nicol mine. ${ }^{15}$ Smaller stocks crop out west of the Logan mine on Bull Hill, and one crops out near the Index mine on Gold Hill. Small irregular masses of syenite have also been cut in the Anaconda tunnel near the Rittenhouse mine and in the Mollie Kathleen mine. Where unaltered, the syenite is a dark-gray granitic rock and consists chiefly of feldspar and black crystals of pyroxene with minor amounts of biotite. Where altered, the dark minerals have been bleached and in part removed, and the rock is light gray to whitish in color.

The phonolite forms extensive flows, which cap several hills in the district; it also forms numerous dikes and a number of extensive sill-like masses that are exposed in several mines. Some of the sill-like masses, like similar masses of latite-phonolite already referred to above, may be buried flows. The unaltered phonolite is a dark-gray dense rock and is commonly sheeted, both at the surface and underground. Prominent phenocrysts of feldspar are rare, and where they are present the phonolite grades into latite-phonolite, and the two rocks can be distinguished one from another only under the microscope. Phenocrysts of dark ferromagnesian minerals, which include sodic pyroxene, sodic hornblende, and biotite, vary in abundance and are small. Most of the phonolite seen underground is altered and is light gray; less commonly it is reddish gray.

The basaltic rocks include trachydolerite, vogesite, monchiquite, and melilite basalt. All are dark gray to blackish gray but are greenish gray where altered. In general, they cannot be distinguished one from another with the unaided eye. They occur most commonly as dikes, but trachydolerite forms a large sill-like mass or flow that caps Bull Cliff. In the Cresson mine breccia of basaltic rock forms an elliptical pipe, which tapers at depth into two roots. This basaltic breccia cuts basaltic dikes but itself is cut by sill-like masses of basaltic rock. ${ }^{16}$ The Cresson pipe of basaltic rocks represents the youngest of the volcanic rocks in the district.

${ }^{14}$ Koschmann, A. H., op. cit., p. 8.

${ }^{15}$ Loughlin, G. F., and Koschmann, A. H., op. cit., p. 249, 1935.

${ }^{16}$ Loughlin, G. F., and Koschmann, A. H., op. cit., pp. 255-56. 


\section{STRUCTURE OF THE BASIN}

The general surface outline of the basin is irregular, but the prevailing trends along its rim, which coincides with the contact between the main central breccia mass and pre-Cambrian rocks, show a marked parallelism and imply that the basin formed by subsidence along vertical or steeply dipping faults initiated along the dominant primary fissures of the region. A structural analysis of the known fissure zones along which intrusion and vein formation occurred, as described below, shows that they accord in direction with the fissures along which the basin formed and are thus related to the structure of the basin. A clear understanding of the form and subsurface structure of the basin is therefore necessary in order that the distribution and arrangement of the known vein fissure zones may be appreciated in appraising unexplored or inadequately explored areas in the district as favorable or unfavorable ground for prospecting.

The form and subsurface structure of the basin are shown on the structure map (pl. 3). In compiling this map the writer has obtained some data from Loughlin's field maps, and data concerning mines that have been inaccessible or have not been visited because of lack of time have been taken from illustrations and descriptions by Lindgren and Ransome in Professional Paper 54.

\section{CONFIGURATION OF THE BASIN}

The Cripple Creek basin is approximately 2 miles wide and 4 miles long. Its longer axis strikes northwest. An inspection of the map (pl. 4) shows that long stretches of the contact between the breccia and pre-Cambrian rock, especially northwest of the Forest Queen mine and southeast of the Cameron mine, are approximately parallel to this northwest axis. Shorter parallel stretches are also present southeast of the Theresa mine, between the Ajax and Carbonate Queen mines, and northeast of Beacon Hill. The northwesterly trend of the long axis of the basin and its marked accordance in strike with long stretches of the contact as well as with many of the subsurface structural features of the basin described below, indicate that the pre-basin fissures of northwesterly trend exerted the dominant control over the outline of the basin.

Locally the walls of the basin follow a zigzag course formed by a series of sharp bends and right-angle turns, the sides of which differ in strike from the major axis of the basin. Such right-angle turns are common along the' south rim of the basin, but similar sharp turns are also present west of the Anaconda 
tunnel, along the west side of the northern part of the basin, and along its southeastern side. The strike of the sides of these sharp turns differs from one part of the basin to another. Along the south rim of the basin they trend alternately westward and northward, whereas in other parts, especially along the west rim of the basin, they trend alternately north-northeastward and northwestward.

The basin is also indented by three conspicuous embayments, which add to its irregularity. The Galena Hill and Cameron embayments are on the northeastern side of the basin and the Masterpiece embayment on the southeastern side. The long axes of the Galena Hill and Cameron embayments strike northeastward, approximately at right angles to the major axis of the basin, whereas the long axis of the Masterpiece embayment is essentially parallel to it. Two smaller embayments, one near the Independence mine along the south rim of the basin and the other near the Unity mine along the west rim, are also worthy of note, as they mark important structures along which intrusion and vein formation occurred.

The basin walls, as indicated in mine workings, are in general steep but irregular. In most places their average slopes range from $65^{\circ}$ to $80^{\circ}$ towards the center of the basin, but they overhang in places, especially along the southwest wall. In other places, however, as in the Cameron mine, they slope as little as $23^{\circ}$, and in still other places the steep walls are locally interrupted at irregular intervals by gently sloping benches, as can be seen in the Ajax, Portland, Queen, and Unity workings. Mine workings have also revealed buried spurs and ridges of pre-Cambrian rocks, and the basin wall, where followed, shows many minor salients and reentrants, all of which indicate that the subsurface structure of the basin is complex.

\section{SUBSURFACE STRUCTURAL FEATURES}

The subsurface structural features of the basin can be deciphered only in a general way. The main basin is composite in structure and comprises three minor basins or sub-basins, separated by buried granite ridges or spurs. In addition, three relatively minor buried granite spurs have been partly outlined underground.

Among the outstanding features of the basin are the two "islands" of pre-Cambrian schist and granite shown on plates 3 and 4 , which are exposed in its central part. The schist island northeast of the Anchoria-Leland mine is the exposed part of one of 
the major ridges. Mine workings reveal that the schist island is continuous underground with the pre-Cambrian rocks to the west. It probably connects also with the granite island to the east, as already pointed out by Lindgren and Ransome, ${ }^{17}$ although this connection has not been exposed underground. This ridge thus separates the basin north of the islands, hereafter referred to as the North sub-basin, from the larger one to the south, referred to as the South sub-basin.

Another ridge or long spur, partly exposed on several levels of the Isabella (Empire-Lee) and Victor mines, exterids southeastward from the granite island. It separates the South subbasin from a smaller one on its northeast side, referred to as the East sub-basin. The extent of this ridge south of the Victor mine is not known, nor is the ridge exposed at a sufficient number of places to fully establish its form. In most places at which solid granite is exposed it grades into rubble or conglomerate of pre-Cambrian rocks, and in some places the contact is poorly defined. Exposures of this ridge in the Isabella mine show the west side locally to dip $30^{\circ}$ to $50^{\circ}$ westward; the east side is not exposed. The absence of pre-Cambrian rocks on level 7 of the School Section mine (altitude 9,330) indicates that the ridge must rise at least 300 feet above the floor of the East sub-basin.

The three relatively small buried spurs of pre-Cambrian rocks are exposed in the South sub-basin. One is exposed in the Portland mine, one in the Carbonate Queen mine, and the third in the Index mine. The relations of the Portland and Carbonate Queen spurs imply the presence of a trough between them. The crest of the Portland spur is exposed on level 15 of the Portland mine, and the northeast slope is well exposed down to the level of the Carlton drainage tunnel (altitude of portal, 6,893 feet), a vertical distance of about 1,900 feet. The west side of this spur is very imperfectly exposed but is, in part at least, overhanging. ${ }^{18}$

The spur in the Carbonate Queen mine is exposed down to the 1,600-foot or Roosevelt tunnel level (altitude, 8,110 feet) just northeast of the Eclipse shaft. It is not present in the projected position in the Roosevelt tunnel 800 feet to the northwest, and the nearest exposures, in the Elkton mine, show the walls of the basin to be overhanging. These relations indicate the presence of a northwestward-pitching spur, parallel to the spur in the Portland mine.

The spur in the Index mine is too poorly exposed to determine

17 Lindgren, Waldemar, and Ransome, F. L., op. cit., p. 30.

${ }^{18}$ Loughlin, G. F., and Koschmann, A. H., op. cit., p. 262. 
its form and character adequately. It is cut at several places. from levels 2 to 5 northeast of the Index shaft but is completely separated from the basin walls by narrow troughs, both to the southwest and northwest. It thus appears to be an immense pillarlike mass of north-northeasterly trend. The shaft has its bottom in gneiss and schist (level 9, altitude, 8,715 feet), and this pillarlike mass of pre-Cambrian rocks may be continuous with the pre-Cambrian wall rocks below this level. The fragmental rock filling the troughs consists of rubble, arkose, and silt composed of pre-Cambrian rock detritus, which is intruded by an irregular mass of syenite that enlarges downward and by numerous dikes of latite-phonolite, phonolite, and basaltic rock. The nonvolcanic fragmental rock in the troughs indicates that this spur-formed in the early stages of development of the basin. The intrusions of igneous rocks indicate reactivation and repeated opening of this fissure zone to admit the successive intrusions, and, as shown below, it finally served as a channel for ore solutions.

\section{FORMATION AND GEOLOGIC HISTORY OF THE BASIN}

A study of the form and subsurface structural features of the basin indicates that it locally developed along new and different sets of fissures during successive stages of its development, which thus repeatedly modified its form and extent. Not only was subsidence intermittent, with periods of quiescence intervening, but during each succeeding period of subsidence movement occurred, locally at least, along entirely new fault planes, so that the basin not only became deeper but was modified in outline. Without subsidence along new fault planes erosion would have rounded off the sharp turns along the south wall of the basin. It would likewise have reduced the slope of the wall to a relatively low angle, which is well illustrated by the eroded wall in the Cameron mine, which, as on level 7, was locally reduced to a dip of $23^{\circ}$. Steep slopes of the wall, such as are found along the south side of the basin, together with its numerous sharp turns, clearly indicate that they represent new fissures along which relatively late subsidence was effected.

Modification in outline of the basin during its development is clearly shown by the discordance between the form of the basin at the surface and its form at depth and its subsurface structural features. Only in the southwestern part of the basin has the contact been exposed at depth at a sufficient number of places to reveal the configuration of the basin with any degree of certainty. 
The present comparison is limited therefore to this part of the basin. The dominant subsurface structural features here found are the granite spurs and the intervening trough. The axes of the spurs and the intervening trough trend northwestward, essentially parallel to the major axis of the basin, and the wall at the southeast end of the trough, as shown on level 9 of the Portland mine, trends northeastward. Locally these trends are also conspicuous on the upper levels and in other parts of the basin at the surface. They suggest that fissures of northwesterly and northeasterly trend were the controlling regional fissures along which the basin was developed in the early stages of subsidence. However, in the upper levels and at the surface along the south rim of the basin, and locally in other places, the stretches of contact of alternate easterly and northerly trend indicate that the relatively late stages of subsidence or development of the basin were guided by a set of fissures discordant with the deeper and hence earlier dominant fissures. Sharp turns at the surface in other parts of the basin wall may bear similar relations to the dominant northwestward-trending fissures in the deeper parts of the basin.

Locally, benches of pre-Cambrian rocks and benches of conglomerate, rubble, arkose, and silt, composed of detritus of the pre-Cambrian rocks, occur at isolated positions along the wall of the basin. Such benches are probably also to be explained by subsidence along a new and different set of fissures during successive stages of development of the basin. Benches of pre-Cambrian rocks are present in the Portland, Ajax, Unity, and Forest Queen mines, whereas benches of nonvolcanic fragmental rocks are found near the breast of the Anaconda tunnel, in the Chicago and Cripple Creek tunnel, ${ }^{19}$ and in the Index mine. The East sub-basin with its basal section of nonvolcanic fragmental rocks may also be considered as one of the benches here described. Some of the benches may represent landslides, but in the absence of an intervening mass of volcanic breccia between the benches and the wall rock they are inferred to be fault blocks.

The local formation of the basin along new sets of fissures during successive stages of its development implies that its floor and walls consist of a mosaic of fault blocks. Subsidence culminated before the intrusion of the igneous rocks and the formation of the veins, but general accordance of the dike and vein fissures with the fissures along which the basin formed indicates that

${ }^{10}$ Koschmann, A. H., New light on the geology of the Cripple Creek district. Colorado, and its practical significance, p. 10, Denver, Colo., Colorado Mining Assoc., January 1941. $839156-49-2$ 
differential and repeated movements of these fault blocks continued afterward.

The distribution of latite-phonolite and phonolite dikes, which are common over a wide area extending into the pre-Cambrian rocks at least 2 miles beyond the breccia (see pl. 3), indicates movement and fissuring of a regional character far beyond the confines of the present basin. On the other hand, the distribution of the basic dikes, except a few in the Strong, Independence, Portland, and Gold King mines, is restricted to the breccia, indicating that movement and fissuring at this stage was limited essentially to the basin. This was followed by another period of movement, more widespread, and the fissures that were now formed became the channels for the ore-bearing solutions. Movement continued at least on a small scale in postvein time, and some of the veins were faulted, as is best shown by the Thompson fault in the Elkton mine ${ }^{20}$ and the Ajax fault in the Ajax mine, ${ }^{21}$ which show displacement of approximately 100 feet, but displacement of veins from 4 to 8 feet is not uncommon.

\section{ORE DEPOSITS}

In following this discussion, especially of the vein fissure zones, the reader will find it advisable to locate these and the various associated features on the accompanying map (pl. 4) and also, if available, on plate 3 of Professional Paper $54^{22}$ or figure 10 in volume 13, number 6, of the Colorado Scientific Society Proceedings. ${ }^{23}$ Plate 3 , although published 40 years ago, shows the most important mine workings of the district from which the positions and arrangements of the most important veins in the mine can be inferred. Figure 10 indicates some of the dominant fissures along which the basin was formed.

The ore deposits of the Cripple Creek district occur chiefly within the fragmental rocks and igneous intrusions that occupy the steep-walled basin, but a few extend into the adjacent preCambrian rocks as, for example, along the south end of the basin and on Beacon Hill west of the basin. Ore bodies at more remote points outside of the basin, as on Mineral Hill and Copper Mountain north of the basin, have been extensively explored, but their number and output are small, and they are not further considered here.

\footnotetext{
${ }^{20}$ Lindgren, Waldemar, and $\mathrm{xan}$ anome, $\mathrm{F}$. x., op. cit.. xop. $333-334$

21 Loughlin, G. F, and Koschmann, $A_{1}, H_{1}$, op, cit, pp, 355-356.

${ }^{22}$ Lindgren, Waldemar, and Ransome, F. L., Geology and gold deposits of the Cripple Creek district, Colorado: U. S. Geol. Survey Prof. Paper 54, 1906.

${ }^{23}$ Loughlin, G. F., and Koschmann, A. H., Geology and ore deposits of the Cripple Creek district, Colorado: Colorado Sci. Soc. Proc., vol. 13, no. 6, 1935.
} 
All the ore bodies, whatever their shape, are causally related to fissures, as already noted by Lindgren and Ransome, ${ }^{24}$ and their localization is principally structural.

In relation to geologic structure the ore deposits of the Cripple Creek district may be divided into three groups: Veins or fissure fillings; irregular deposits in shattered rock; and mineralized "collapse breccia." Some of the veins are fillings of single fissures, but more commonly they consist of mineralized sheeted zones as much as 10 feet or more wide, each of which comprises a series of approximately parallel closely spaced narrow. fissures. The irregular deposits have formed by mineralization of shattered rock at the intersections of two or more fissures or fissure zones. Collapse breccia deposits, described by Loughlin, ${ }^{25}$ consist of rubblelike masses of pipelike form where shattered ground has been corroded and the rounded fragments are coated by vein minerals. The collapse breccia may grade upward and outward into shattered ground.

The localization of the vein fissures is related primarily to the major structural features and configuration of the basin and only secondarily to the physical character of the rocks. One of the outstanding features of the vein fissures in the Cripple Creek district, shown diagrammatically on plate 4, is their arrangement in relatively long narrow zones that are separated one from another by broad relatively barren areas. Most of the vein zones are close to the contact between the breccia and the pre-Cambrian rocks; some are wholly within the breccia masses, but some extend into the pre-Cambrian wall rocks. A study of the map shows (1) that many of the vein fissure zones that are close to the contact occur at abrupt bends or recessions along the contact, (2) that some of the fissure zones coincide with or parallel the dominant local trends of the contact between the granite and breccia, and (3) that other fissure zones coincide with or parallel the major subsurface structural features of the basin, such as the granite ridges and spurs. Some fissure zones though not directly related to known structural features are parallel to such features and thus suggest that they are probably genetically related to buried parallel structural features.

Although the localization of the vein fissures and fissure zones was primarily controlled by the major structural features of the basin, locally other factors, particularly the physical character and structure of the host rocks, influenced their distribution and

${ }^{24}$ Lindgren, Waldemar, and Ransome, F. L., op. cit., p. 153.

${ }^{25}$ Loughlin, G. F., and Koschmann, A. H., op. cit., pp. 299-301. 
arrangement and especially their extent. The most favorable host rocks are those that tended to yield most readily to fissuring. Vein fissures occur in all types of rock, but along any one fissure zone they are most abundant in the breccia. Many vein fissures follow dikes, especially the phonolite and basic dikes. These dikes have a tendency to develop platy parting parallel to their walls and are sheeted where they lie in and parallel to the zone of fissuring. The association of veins with dikes is not due, as is commonly believed by many miners in the district, to any genetic relation between the dike rocks and ore solutions. Where the vein fissures intersect dikes, sills, or the larger irregular intrusive bodies, at right angles, or nearly so, the fissures are either tight within such rocks or terminate at the contact. This is well illustrated by the Captain system of veins in the Portland mine, which terminates at the contact with a mass of latite-phonolite, ${ }^{26}$ and by some of the vein fissures in the Vindicator mine, some of which terminate at the contact with the syenite, whereas others are deflected into the breccia close to the margin of the syenite. ${ }^{27}$

The conformity between many of the vein fissure zones and the corresponding local structural feature of the basin, which indicates their genetic relations, implies postbasin movement along many of the preexisting master fissures that bound the basin and favors exploration along analogous structural features along the basin wall as yet unexplored or inadequately explored. The genetic relations between vein zones and structure of the basin imply further that those fissure zones that are related to subsurface structural features, and hence are upward extensions of the controlling primary fissures in the floor of the basin, will persist down the dip to the primary fissure or structural feature. These deep-seated fissures presumably were the trunk channels that tapped the igneous reservoirs and were the channels along which the ore solutions rose. Although most of the major zones of fissuring may be deep-seated, a study of the veins along them shows that in general they become fewer and more restricted in distribution with depth, and the vein zone thus becomes increasingly narrow. Accordingly, ore shoots, as already pointed out by Loughlin, ${ }^{28}$ will become fewer with depth and will converge toward the relatively few deep sources of the ore solutions, and only mines that overlie these deep sources will respond favorably to deep development.

\footnotetext{
${ }^{26}$ Loughlin, G. F., and Koschmann, A. H., op. cit., p. 333.

${ }^{27}$ Loughlin, G. F., and Koschmann, A. H., op. cit., pp. 372-374.

${ }^{28}$ Loughlin, G. F., and Koschmann, A. H., op. cit., p. 413.
} 
The following brief description of the vein zones is intended to outline their relations to the structures along the walls of the basin or to its known subsurface structural features and from such a structural study to point out undeveloped places in the district with apparent favorable structural setting where further exploration for ore is worthy of consideration and places along the known vein zones where deep exploration seems justified. For a discussion of the mechanics of rock fracturing and additional discussion of conditions that control the downward continuity of ore zones and the localization of ore shoots the reader is referred to the report by Loughlin and Koschmann. ${ }^{29}$

\section{VEIN ZONES IN THE SOUTH SUB-BASIN}

EMPIRE-VICTOR VEIN ZZONE

The Empire-Victor vein zone is the easternmost of several major northwestward-trending vein zones. It coincides approximately with the southwest side of the buried ridge of granite in the Isabella mine, described on page 29 , and clearly illustrates the mutual structural relations between a vein zone and the local subsurface structure of the basin. The vein zone is 200 to 400 feet wide and has been explored for a distance of about 3,700 feet, from the Empire mine to a point about 550 feet southeast of the Victor shaft. Near the Empire shaft the zone is intersected by several cross veins of easterly and northeasterly trend (see p. 45), northwest of which it appears to be only weakly developed, if at all. Its southern limit is not known. The average strike of the zone is $\mathrm{N} .48^{\circ} \mathrm{W}$., and the vein fissures dip westward. The vein zone consists of short veins chiefly in step-like arrangement. Some are parallel to the strike of the zone, and others diverge. Fault gouge, 3 feet and more thick, is locally present along some of the veins, and the vein zone undoubtedly is a distributive fault zone. This zone also contains an irregular though dikelike mass of latite-phonolite ${ }^{30}$ and typical dikes of all the intrusive rocks, indicating that it has been periodically fissured. The close accordance in distribution and trend of the faults, veins, and some of the intrusions with the southwest side of the buried granite ridge indicates that this fissure zone is the upward extension of the master fissure along which the west wall of the granite ridge was formed.

The genetic relations between the fissure zone and the subsurface structure of the basin imply the persistence of the fissure

20 Loughlin, G. F., and Koschmann, A. H., op. cit.

${ }^{30}$ Lindgren, Waldemar, and Ransome, F. L., op. cit., pp..389-90, figs. 45, 56. 
zone to considerably greater depth than the present extent of mine workings. This vein zone has been explored to a depth of about 1,100 feet, and, although only small ore shoots have been found on the lower levels, exploration there has not been exhaustive. In the Vindicator mine, which lies along the vein zone immediately to the west of the Empire-Victor zone, ore has been mined about 1,500 feet deeper than along the Empire-Victor zone and in the Portland mine about 2,500 feet deeper. The general character and grade of ore in the deepest shoots in the district and the general uniformity in mineral composition from the shallowest unoxidized to the deepest exposures, as pointed out by Loughlin, ${ }^{31}$ give no indication of an approach to the ultimate depth at which ore could form or at which fissures become too tight and small for profitable mining. In the light of its structural setting and of profitable mining in other parts of the district at much greater depths than so far attained along the Empire-Victor zone, search for ore in this zone is justified at a depth comparable with that of other deep fissure zones in the district.

\section{VINDICATOR-SOUTH BURNS VEIN ZONE}

The Vindicator-South Burns vein zone, one of the longest and most productive in the district, trends northwestward and is essentially parallel to the Empire-Victor zone. It extends from the Theresa mine on the southeast to the South Burns mine on the northwest. In the workings of the South Burns mine it is intersected by a set of vein fissures of northeasterly trend, of which the Eagles, Findlay, and Wilson cross veins are the most prominent; beyond these it is only weakly developed. Because of the absence of mine workings south of the Theresa mine the southern limit of this zone is not known.

The average strike of this zone between the Vindicator and South Burns shaft is N. $42^{\circ}$. W. South of the Vindicator shaft, however, the strike becomes more southerly, suggesting that the zone developed along two master fissure zones, similar to that of the Portland-Independence-Ajax zone, described below. South of the Vindicator shaft this zone is approximately in line with the short northward-trending part of the breccia-granite contact south of the Theresa shaft. This relation suggests that the veins south of the Vindicator shaft are in a fissure zone that played a part in the outlining of the basin. The northwestward-trending portion of the zone, because of its trend parallel to the Empire-

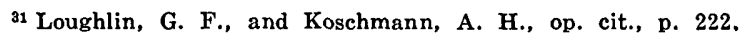


Victor zone, is regarded as the upward extension of a master fissure zone in the underlying granite.

This vein zone, which lies entirely within the breccia mass, follows an intrusive zone that contains dikes of all the igneous rocks of the district, several irregular bodies of latite-phonolite, and a ramifying stock of syenite. ${ }^{32}$ These relations point to the formation of the fissure zone along a persistent zone of weakness that has been repeatedly reopened. The intersection of the northwardtrending and northwestward-trending fissure zones apparently formed an axis of weakness of profound depth; this became the local intrusive center of the syenite stock. The ore shoots to the north and south of the Vindicator mine ${ }^{33}$ pitch toward this center, indicating that the intrusive center was probably also the local deep source of the ore solutions.

Correlation of the fissure zone with a deep-seated structural feature in the floor of the basin implies general downward persistence of the vein zone, and accordingly deep prospecting below the explored levels at the most encouraging places is warranted. As the pitch of the ore shoots suggests that the local deep source of the ore solutions was beneath the junction of the northwardtrending and northwestward-trending vein zones, which also coincides with the intrusive center indicated by the syenite stock, deep prospecting here along the most persistent veins should prove the most successful. The deepest ore shoots so far found, on levels 20 and 21 of the Vindicator mine, approximately overlie this indicated source, and, although these shoots were small, it is not improbable that this general level represents merely a relatively barren interval, like that between levels 21 and 23 in the Portland mine, ${ }^{34}$ and that ore shoots may be present at a lower level.

The occurrence of veins along the strike of this zone south of the Theresa mine is also considered favorable. The change in strike of the zone south of the Vindicator mine from a northwesterly to a northerly trend, as already outlined, and its general alinement with the short northward-trending part of the brecciagranite contact south of the Theresa shaft suggest that a zone of fissuring persists south of the Theresa shaft probably into the granite. This zone would be parallel and probably analogous to the northward-trending fissure zone of the Independence-Portland-Ajax zone. A mass of latite-phonolite has been intruded near the breccia-granite contact and may have sealed or adversely affected fissuring. However, latite-phonolite is older than the

\footnotetext{
${ }^{32}$ Loughlin, G. F., and Koschmann, A. H., op. cit., pp. 372-74.

${ }^{33}$ Loughlin, G. F., and Koschmann, A. H., op. cit., pp. 374-76.

st Loughlin, G. F., and Koschmann, A. H., op. cit., p. 336.
} 
vein fissures of the district, and similar intrusives on the upper levels of the Vindicator mine apparently have not adversely affected fissuring there. The structural setting warrants exploration south of the Theresa mine.

\section{INDEPENDENCE-PORTLAND-AJAX VEIN ZONE}

The Independence-Portland-Ajax vein zone is a composite network of veins centered about the middle part of the south wall of the basin. It extends approximately from the Independence mine westward for about 2,500 feet, or about 700 feet west of the Ajax and Gold Coin shafts and northward for about 3,500 feet to the Portland No. 3 shaft. Unlike other known vein zones in the district, except those on Beacon Hill, it extends across the breccia-granite contact.

The breccia-granite contact at the surface makes a sharp rightangle turn formed along master fissures of northerly and westerly trends. Below level 11 of the Portland mine, however, as already described (pp. 30-31), the local structure of the basin is significantly different. Extending from the sharp turn or salient of granite is a relatively narrow granite spur, which was formed along a master fissure of northwesterly trend. The local development of the basin along master fissures of northerly, westerly, and northwesterly trends implies the probable existence of sets of fissures of corresponding trends throughout the granite. Vein fissures in the Portland zone that accord in trend with the adjacent or subsurface structural features are attributed to reopening of favorably situated fissures in the granite or to movement of the breccia relative to the granite along master fissures that controlled the local structure of the basin.

On the basis of strike, the more important vein fissures in this zone can be divided into two sets-one of northerly strike and the other of northwesterly strike. Those of northwesterly strike can be subdivided into a set with northeast dip and another with southwest dip. Veins of northerly strike dominate in the granite and those of northwesterly strike in the breccia. These two sets overlap, and veins of both sets are common in the intermediate ground that lies close to the contact. The northwestward-trending No. 1 vein of the Portland mine, which closely parallels the breccia-granite contact along the northwest side of the buried granite ridge, is joined on level 17 by a fourth set of veins of north-northeasterly trend, called collectively the East vein. This set extends from a point near the Portland No. 2 shaft to the Wisconsin claim, where it curves through a northerly to northwesterly. 
course ${ }^{35}$ and becomes the East vein-Orpha May vein zone, described below.

The No. 1 vein in the Portland mine and the Independence vein, which are parts of one continuous vein; as already mentioned, coincide with the breccia-granite contact on the northeast side of the granite spur. On the upper levels where the contact becomes less steep and above the crest of the spur, they extend upward into the breccia and maintain uniform dips and strikes until they branch into a number of subordinate veins. This fissure also contains latite-phonolite and phonolite dikes, and these relations clearly show that this fissure is deep-seated and was formed by recurrent movement along one of the master fissures along which the basin was formed.

Although the relatively short and widely dispersed veins of northwesterly trend in the breccia close to the granite contact, lying mainly south of a line passing through the Ajax and Portland No. 1 shafts, are parallel in strike to the No. 1 vein, they dip southwest and therefore cannot be regarded as genetically related with the No. 1 vein. Few, if any, pass from the breccia into the granite, either along the strike or down the dip. ${ }^{36}$ Their general restriction to the breccia and their downward termination at the contact between the breccia and granite suggest that they were formed through movement of the breccia, and they are therefore interpreted as tension fissures formed by the relative downward movement or settling of the breccia along the granite contact.

The short closely spaced steplike veins in the group lying chiefly north of the Portland No. 2 shaft, known as the Captain-Hidden Treasure veins, also trend northwestward and are suggestive of. an origin similar to the group of northwestward-trending veins just described. Although the veins in this set individually trend northwestward, the group as a whole trends northeastward. They occur only in the upper levels of the Portland No. 2 mine and lie vertically above the East vein of the Portland mine, ${ }^{37}$ which also trends north-northeastward. Their arrangement and strike accord with tension fissures that might be produced by a shearing movement along the East vein or a parallel fissure in which the east wall tended to move northward. The veins occur in breccia, which is in part bounded by an irregular body of latite-phonolite. Apparently the latite-phonolite resisted fracturing, whereas the

\footnotetext{
ss Loughlin, G. F., and Koschmann, A. H., op. cit., pp. 334-336.

${ }^{36}$ Lindgren, Waldemar, and Ransome, F. L., op. cit., fig. 62 and pl. 29.

37 Loughlin, G. F., and Koschmann, A. H., op. cit., figs. 27, 30 .
} 
breccia yielded, which thus accounts for the restricted distribution of this group of veins. ${ }^{38}$

The vein fissures in the granite parallel the master fissures along which the basin formed and, as already mentioned above, are therefore interpreted as products of late movement within the granite during which favorably situated old fissures were reopened. This is illustrated by the Strong vein, which follows a zone of latite-phonolite, phonolite, and basaltic dikes; but some parallel fissures, not occupied by dikes, are probably newly formed. In the embayment east of the Dillon shaft some of the veins extend from the granite across the contact into the breccia that overlaps onto the moderately sloping or shelving granite, but west of the Dillon shaft they do not penetrate the breccia to any appreciable extent, nor is the contact dislocated, indicating fissuring without appreciable movement.

Ore has been mined in the Portland mine to a maximum depth of about 3,000 feet, the greatest depth attained in the district, but whether conditions have favored the formation of veins of minable size and grade at greater depth cannot be predicted. Both the local structural features of the basin and the relatively wide distribution of the fissures in the granite imply thorough fissuring of the granite. From these relations it is reasonable to believe that in a zone so thoroughly fissured those veins most persistent along the strike would also persist for considerable distances below the 3,000 foot level, but ore shoots will probably become smaller and more widely separated with depth.

\section{EAST VEIN-ORPHA MAY VEIN ZONE}

The East vein-Orpha May zone has been traced essentially across the basin, extending from the granite spur in the Portland mine (see pp. 38-39) into the Logan and Ameriçan Eagles minès, where it stops against northeastward-trending veins. This vein zone, between the Last Dollar and Logan mines, has an average strike of about N. $35^{\circ} \mathrm{W}$. and is essentially parallel to the Vindicator-South Burns and the Empire-Victor zones, but south of the Last Dollar shaft it curves southward and then south-southwestward.

This vein zone is entirely in the breccia mass, and the explanation regarding its structural control is therefore not as fully supported as might be desirable. Because of the arrangement of the veins in a long narrow zone, the northern part of which is parallel in trend to the extensive northwestward-trending vein zones to

${ }^{3 s}$ Loughlin, G. F., and Koschmann, A. H., op. cit., p. 333. 
the east and to the dominant northwestward-trending subsurface structural features, such as the buried granite ridges, it is attributed to differential movement along a dominant fissure or structural feature of corresponding strike in the floor of the basin. However, the portion of this vein zone trending southward and south-southwestward south of the Last Dollar mine cánnot be correlated with any known parallel subsurface structural feature close by, and its control can only be conjectured. It is in general in alinement with the northeastward-trending wall along the southeast end of the trough southwest of the spur in the Portland mine and may represent a corresponding fissure zone on the northeast side of the spur, but until more data are available further speculation is not warranted.

Although the extent of this zone across the basin and its inferred structural relation with a master shear zone in the granite floor suggest the downward continuity of the vein zone as a whole, it has not responded to deep mining except at the south end, and exploration deeper than that already undertaken north of the Last Dollar shaft does not appear encouraging. The local source of the ore-forming solutions was evidently below the large syenite intrusion in the Last Dollar mine, as already pointed out by Loughlin,,$^{39}$ and conditions here warrant further study for favorably situated structural features.

\section{CRESSON-ROSE NICOL VEIN ZONE}

The Cresson-Rose Nicol vein zone comprises an isolated network of short scattered veins of diverse trends centered around the Cresson "blowout," or elliptical pipe of basaltic breccia, in the central part of the South sub-basin. The veins lie chiefly to the east and south of the Cresson blowout and within its elliptical pipe of breccia, but a few short veins have also been worked west of the blowout; the area north of the blowout is essentially barren except for a few veins in the Joe Dandy mine. Although there is no over-all uniformity in the trend of these veins, most of those east of the blowout trend northward, and most of those along the south side of the blowout, both within and immediately south of it, as well as the longer axis of the blowout itself, trend northeastward; a few veins along the south side of the blowout trend northwestward. The isolated position of this network of veins in the central part of the basin, the absence of any linear arrangement of the veins, and the difference in their prevalent strike in different parts of the zone suggest that this group of vein fissures

${ }^{39}$ Loughlin, G. F., and Koschmann, A. H., op. cit., pp. 341-342. 
formed along three fissure zones. This vein group falls approximately at the intersection of (1) the northeastward-trending fissure zone that is prevalent along the southeast side of the granite island, (2) the projected position of the northward-trending fissure zone along the south wall of the basin, and (3) the approximate projected position of the northwestward-trending master fissure along the northwest side of the granite spur in the Portland mine. From their structural setting and arrangement it is inferred that these veins are genetically related to and mark the outlying members of these three zones.

The isolated position of this vein group and the great depth to which ore has persisted in the pipe of basaltic breccia, ${ }^{40}$ and conversely the relative shallowness of the ore shoots in the veins in the immediately surrounding area, indicate that the pipe of basaltic breccia was the local permeable zone followed by the oreforming solutions; hence the blowout offers the most favorable site for the local downward continuity of ore shoots. The blowout, and therefore the fissures along which the blowout formed, certainly persist downward for a long distance. The localization of the deepest ore shoots within the blowout implies that these same deep-seated fissures that tapped the igneous reservoir afforded the principal channels along which the ore-forming solutions rose, and accordingly the downward continuity of ore shoots here seems a reasonable expectation.

\section{CARBONATE QUEEN VEIN ZONE}

The Carbonate Queen vein zone is one of the minor zones in the district and is not known beyond the workings of this one mine, although the dike of latite-phonolite exposed on level 16, which curves from a northeasterly to a north-northwesterly course, is essentially continuous with similar dikes in the Moose mine. The dominant vein fissures trend north-northwestward and dip steeply south-southwest toward the granite contact. Minor veins trend east-northeastward. A few veins are coincident with dikes that also trend chiefly north-northwestward and east-northeastward. The veins are in breccia approximately opposite the right-angle bend along the contact northwest of the Ajax mine, which shows the close relation between vein zones and structure of the basin.

Although the breccia-granite contact south of the Eclipse shaft makes a right-angle turn at the surface, mine workings show that the contact below level 5 trends north-northwestward, dips steep-

${ }^{40}$ Loughlin, G. F., and Koschmann, A. H., op. cit., pp. 311-327. 
ly to the northeast, and forms the northeast slope of a northwestward-pitching granite spur, analogous to the spur in the Portland mine. The dominant vein fissures accord in position and strike with the northeast side of the granite ridge and are clearly products of relative movement between the breccia and granite. The fissures of north-northwesterly trend accord with tension fissures resulting from settling of the breccia along the northeast side of the granite spur. The short fissures of east-northeasterly trend are too local to be reliably interpreted, but they accord approximately in strike with the eastward-trending contact at the surface, which suggests that they were formed by subsidiary movement along this contact.

The Carbonate Queen ground has not been exhaustively explored and offers favorable ground for prospecting both below the developed levels of the mine and in the granite south of the sharp turn along the contact. The Carbonate Queen mine was studied by Loughlin. ${ }^{41}$. He described the favorable ground below the mine workings as follows:

Development along the granite contact on level 16 (Roosevelt tunnel level) has exposed the intersections of a north-northwesterly vein and an east-northeasterly vein 170 feet northeast of the shaft. Both veins consist of first-stage fluorspar, and the north-northwesterly vein has been shattered and recemented by minerals of the second and third stages, including an encouraging amount of telluride. A short distance south of the intersection the main vein curves southeastward and leaves the granite contact. It returned favorable assays for 70 feet from the intersection and appeared rather open as far as a point almost directly beneath the old Carbonate Queen shaft. *** The ore-forming solutions evidently rose along the intersection noted above and contirued upward along available openings to form ore shoots on higher levels, as suggested in figure 39 . The intervening unexplored ground, therefore, deserves attention.

Loughlin ${ }^{42}$ also considered several other places along the extension of the vein zone to the northeast as favorable for exploration.

The similarity between the structure of the basin near the Carbonate Queen mine and that near the Portland and Independence mines, where many productive veins are present in the granite, suggests that veins may be present in the granite south of the Carbonate Queen mine. The numerous productive veins in the granite from the Independence mine westward for at least 3,000 feet clearly reveal that the granite near the contact over a broad belt has been thoroughly fissured, a condition also reflected by the right-angle turns and jogs along the contact. Because of

41 Loughlin, G. F., and Koschmann, A. H., op. cit., p. 363.

42 Loughlin, G. F., and Koschmann, A. H., op. cit., pp. 363-364. 
the relatively thick cover of wash and float, prospecting has been meager, but in the light of the favorable structural conditions here systematic prospecting along this zone deserves consideration.

\section{ELKTON VEIN ZONE}

The Elkton vein zone is the westernmost of the vein zones along the south wall of the basin. The arrangement of the vein fissures is of relatively simple pattern compared with the others farther east. It comprises two sets of fissures, a dominant set of northerly trend and a set of local cross fissures of easterly trend (not shown on map). The fissures of northerly trend, which include the Walter, Henly, and Raven, are the most persistent, both along the strike and down the dip, and have been the most productive. The northward-trending veins coincide with or parallel basic dikes, indicating recurrent movement along this zone.

The breccia-granite contact at the surface trends essentially westward, but its dip, as shown in mine workings, is vertical to $80^{\circ} \mathrm{S}$.; thus it is steeply overhanging. Just south of the Elkton shaft the contact turns sharply to the south for about 150 feet, making a minor jog along the contact. Where exposed on and above level 7 it makes a corresponding jog, thus showing a persistent dislocation of the wall, presumably along a northwardtrending fissure, the east wall of which apparently moved south. The dominant northward-trending vein fissures intersect the contact approximately at the jog, clearly indicating again the genetic relation between the vein fissures and the fissures along which the basin was formed. The eastward-trending cross veins are essentially parallel to the contact and are either upward extensions of fissures in the floor of the basin or, more likely, tension fissures opened up by settling of the breccia along the contact.

Results obtained by exploration both in depth and along the strike south of the granite contact have not been encouraging as far as new ore discoveries are concerned. Although the ore shoot was continuous from the surface down to level 11 and maintained a length of 1,500 feet or more, it shortened abruptly below that level, and on the Roosevelt drainage tunnel level (level 18) only one small shoot 30 feet long was found, indicating progressive tightening of the dominant vein with increasing depth. The main, or Walter, vein has been followed a short distance into the granite, and a small ore shoot was found just south of the contact,43 but this shoot apparently was too small to encourage extensive development. The long even wall of the basin, exclusive of the

${ }^{43}$ Lindgren, Waldemar, and Ransome, F. L., op. cit., p. 338. 
minor break at the Elkton, the broad barren zones on either side of the Elkton, the small amount of offset along the contact, and the simple pattern of the Elkton vein zone imply only minor fissuring in this part of the basin. With so many unfavorable elements entering the picture, the probable extension of this vein zone down the dip or into the granite appears unlikely, and prospecting there must be considered a decided gamble.

NORTHEAST VEIN ZONE SOUTH OF THE GRANITE "ISLAND"

Vein fissures of northeasterly trend have already been alluded to in the description of the northwestward-trending vein zones, which essentially terminate at their intersection with these northeastward-trending veins. Attention is here directed to their arrangement and their distribution relative to the structure of the basin. Although this vein zone can be traced from the Cresson blowout northeastward to the granite ridge in the Isabella mine, a distance of about 6,500 feet, this zone consists of discontinuous veins or sets of parallel veins with northwest dip in apparent steplike arrangement. Few have been followed any considerable distance beyond ore shoots, and hence their individual lengths are not known, but many extend beyond the vein limits shown and may extend from one northwestward-trending vein zone to the adjacent zone. The proximity of the more pronounced of these northeastward-trending veins to the contact along the southeast side of the granite island and their general dip toward the contact indicate that they are tension fissures genetically related to subsidence of the breccia southeast of the granite island and west of the granite ridge in the Isabella mine.

Ore shoots in the northeastward-trending veins are essentially restricted to their intersection with the northwestward-trending fissures and elsewhere are prevailingly tight. The relative shallowness of the workings along these veins and the barren character of the veins away from their intersections with the northwestward-trending veins suggest that the ore solutions were supplied from the northwestward-trending fissures. These relations and the northwest dip of the veins into the granite, which should bring them into contact with the southeastward-sloping granite at moderate depth, ${ }^{44}$ suggest that ore shoots will not continue to deep levels and do not encourage deep exploration.

\section{MARY MCKINNEY-MORNING GLORY VEIN ZONE}

The Mary McKinney-Morning Glory vein zone and the EI Paso vein zone rank with the most extensive and productive vein zones

4t Loughlin, G. F., and Koschmann, A. H., op. cit., p. 382. 
of the district. Their structural setting shows that they probably form one complex system closely related genetically. However, as one lies in the breccia and the other in granite and as they show in detail differences in the number of vein fissures and in structural controls, a separate treatment of each vein zone is warranted to simplify the discussion.

The Mary McKinney-Morning Glory vein zone lies in the southwest corner of the South sub-basin and is the southernmost of a series of vein zones, mainly of northeasterly trend, that prevail along the west side of the basin. This vein comprises three or more sets of fissures-the Mary McKinney, the Morning Glory, and one or more sets of short cross veins. The Mary McKinney set trends north-northeastward, passes from the Unity through the Mary McKinney mine, and continues nearly to the schist island. It has a known length of about 5,000 feet. Toward its north end it is reported ${ }^{45}$ to turn northeastward and apparently feathers out. The Morning Glory set of vein fissures trends about $\mathrm{N}$. $45^{\circ}$ E. and has a known length of about 4,000 feet. About 1,500 feet northeast of the Morning Glory shaft it intersects one of the cross veins of northwesterly trend and apparently feathers out beyond. The Mary McKinney and Morning Glory sets of vein fissures converge to the southwest and join approximately at the breccia-granite contact, where they apparently merge with the El Paso vein zone described below.

An inspection of the map shows that the Mary McKinneyMorning Glory vein zone conforms with the northwest wall of the Unity embayment, formed at the intersection of the south and west walls of the basin. The most persistent veins in the Mary McKinney network are the long Mary McKinney vein and several short parallel veins of north-northeasterly trend that dip steeply to the west. Parallel veins, but of steep easterly dip, together with several cross veins of northwesterly and west-southwesterly trend, form the northern part of this network of veins. The parallelism between the north-northeasterly veins and the contact along the northwest wall of the Unity embayment and the west dip of these veins imply that they are tension fissures effected by subsidence of the breccia along the contact. The origin of the veins of north-northeasterly trend and easterly dip in the northern part of this vein zone is less evident. They are parallel to the contact in dip as well as in strike and may possibly be the upward extension of a master fissure in the floor of the basin. The cross vein fissures of northwesterly trend, both in the Mary

45 Lindgren, Waldemar, and Ransome, F. L., op. cit., p. 309. 
McKinney and Morning Glory zones, are parallel to the northwestward-trending stretches of the contact and were probably formed by minor movement of the breccia parallel thereto.

The Morning Glory vein system comprises one long vein, known as the Doctor-Jackpot, several short parallel veins of northeasterly trend, several short cross veins of northwesterly trend already described above, and several short veins east of the Morning Glory shaft of somewhat random trend, among which those of north-northeasterly trend are the most common. The cross veins are probably genetically related to and are local members of parallel veins of the Mary McKinney system. Available information is insufficient, however, to permit a wholly satisfactory interpretation regarding the control of the long northeastwardtrending Doctor-Jackpot vein fissures. Its marked divergence in trend from the dominant Mary McKinney veins of north-northeasterly trend and the fissure that controlled the northwest wall of the Unity embayment suggests that the Doctor-Jackpot is structurally related to a concealed subsurface structural feature. It is essentially parallel to the northeastward-trending fissures southeast of the granite island and the master fissure that controlled the southeast side of the granite island, which suggests that the Doctor-Jackpot fissure is the upward extension of a master fissure in the granite floor. It is also in alinement with and parallel to the long C. K. \& N. vein fissure of the El Paso vein zone, which extends for half a mile to the southwest in granite and together with the master fissure that localized the southeast side of the granite island indicates that northeastwardtrending fissures may be locally present in the granite floor.

The probable source of the ore solutions and the possible downward continuity of these veins are considered after the discussion of the El Paso vein zone.

\section{BEACON HILL VEIN ZONES}

Beacon Hill, which adjoins the Unity embayment on the southwest, contains two essentially parallel vein zones, the El Paso and Mable M., which lie, respectively, on the northwest and southeast sides of the Beacon Hill elliptical knoblike plug of phonolite. The phonolite plug is about 2,200 feet long in a north-northeasterly direction and about 1,200 feet wide and tapers irregularly downward into a dike about 100 feet thick on the Roosevelt tunnel level. ${ }^{46}$

The El Paso zone consists of a set of parallel vein fissures that

${ }^{46}$ Loughlin, G. F., and Koschmann, A. H., op. cit., p. 290. $839156-49-3$ 
strike approximately N. $35^{\circ} \mathrm{E}$. and dip $70^{\circ}-75^{\circ} \mathrm{NW}$. and a cross vein, called the C. K. \& N. vein, that ranges in strike from northeast to east-northeast. At the northeast end, near the north end of the phonolite plug, the C. K. \& N. vein forks; one branch trends northeastward and joins the Morning Glory veins, of which it probably forms the southwest extension, and the other trends east-northeastward.

The northeastward-trending set of vein fissures consists of a group of closely spaced relatively short fissures. Some are sheeted and locally contain gangue of sheared granite and crumbly pyrite, ${ }^{47}$ and several displace the C. K. \& N. vein. Their character and displacement of the C. K. \& N. vein fissure clearly show that they form a shear zone of closely spaced distributive faults and were formed subsequent to the reopening of the C. K. \& N. fissure.

The structural setting of the El Paso vein zone southwest of the Unity embayment, one of the conspicuous structural features of the basin, and its alinement and conformity in strike with the long northeastward-trending wall at the northwest side of the embayment point to an obvious genetic relation between them. The set of northeast veins, as shown by their alinement to and parallelism with this wall of the embayment, evidently mark the southwest extension of the master fissure along which the embayment was formed. Locally some of these veins coincide with phonolite dikes, which, together with their relation to the structure of the embayment, indicates that this master fissure zone has been a persistent zone of weakness that began during the early stages of subsidence of the basin.

The C. K. \& N. vein, as already pointed out above, is the probable southwest extension of the Doctor-Jackpot vein of the Morning Glory system. The persistence of this fissure, both in the granite and breccia, and its general parallelism with the southeast wall of the granite island suggest that it represents a set of fissures in the granite that were locally reopened along zones of weakness.

Data on which to base suggestions regarding the local source of the ore solutions and the probable downward persistence of the veins are meager. No new essential structural data have been published on the Mary McKinney or Morning Glory veins since those given in Professional paper 54. The mine workings along these veins and many of the workings along the El Paso vein zone also have been inaccessible. Considering the great total length of the El Paso-Mary.McKinney vein zone, its genetic re-

47 Lindgren, Waldemar, and Ransome, F. L., op. cit., p. 352. 
lations with one of the most pronounced fissures along which the basin formed, and its persistence as a zone of weakness, there can be little doubt that this vein zone continues to considerable depth, and deep exploration is warranted. However, without more information regarding the local structure on the deepest levels and the pitch of the ore shoots, no specific suggestions can be offered regarding favorable locations for such deep exploration. In other parts of the district local sources of ore solutions and the deep ore shoots are close to the edge of the basin or at the intersections of dominant fissure zones. Accordingly, it seems more likely that the ore along this zone was derived from a source near the breccia-granite contact, as already suggested by Loughlin, ${ }^{48}$ which also approximately coincides with the intersection of the nearby Mary McKinney and the Morning Glory vein fissures.

The Mabel M. vein zone is parallel to the El Paso vein zone and lies on the southeast side of the Beacon Hill plug of phonolite. The Mabel M. zone consists of two sets of veins, one of northerly trend and the other of northeasterly trend. All veins dip steeply westward. The zone extends approximately from the Gold Dollar mine northeastward through the Mabel M. mine and has a known length of about 1,200 feet. It is in line with the jog along the breccia-granite contact that forms the short southeast wall of the Unity embayment, and, although it has not been traced to the contact, its structural setting suggests that the fissure zone probably continues to the contact and possibly beyond into the breccia. From its apparent structural relation to the Unity embayment it is inferred that the Mabel M. vein zone is the southwest extension of the northeastward-trending fissure zone that localized the short wall on the southeast side of the embayment and is the counterpart of the El Paso vein zone.

Although the structural setting favors the continuation of the Mabel M. vein zone to the northeast and indicates the undeveloped portion as favorable ground for prospecting, several features detract from its promising aspects and should be considered in any plan for prospecting it. The known ore bodies are not as large and extensive as those along the El Paso vein zone and as a whole have been less productive. Furthermore, where the Roosevelt drainage tunnel crosses the Mabel $M$. vein zone along the projected dip and strike, no encouraging veins were found, and this fact, together with the relatively small size and extent of its known ore bodies, clearly indicates that the Mabel M. fissures are relatively tight. The small jog on the southeast

48 Loughlin, G. F., and Koschmann, A. H., op. cit., pp. 401-402. 
side of the Unity embayment also suggests that fissuring along the northeast extension of the Mabel M. zone is less intense and thorough than along the El Paso zone. However, in spite of these unfavorable aspects the Mabel M.'zone cannot be ruled out as a prospect worthy of consideration, and it is possible that exploration along the trend of this zone may open up favorable territory on the upper levels.

\section{VEIN ZONES IN THE MOON ANCHOR EMBAYMENT}

In the constricted northwestern part of the South sub-basin southwest of the schist island, which will be referred to as the Moon Anchor embayment, several small vein zones and isolated veins are found, all close to the contact. Along the west wall near the south end of the embayment is the Index vein zone. About 2,000 feet to the north is the Moon Anchor zone, and immediately north of it is the Conundrum vein. East of the Moon Anchor zone, near the east wall of the embayment, lies the AnchoriaLeland-Geneva zone, and at the head of the embayment along its northwest wall is the Abe Lincoln network of veins. These vein zones conform on the whole to the local geologic structural features and like those of neighboring areas emphasize the influence of local structural features on their distribution.

The Index vein zone lies in the apex of the most conspicuous reentrant angle along the west wall of the basin. The vein zone comprises a persistent vein fissure, known as the Pointer vein, several parallel veins striking about $\mathrm{N} .30^{\circ} \mathrm{E}$., and several minor irregular and short veins of diverse trends. The most persistent northeastward-trending vein fissures are on the northwest side of and are parallel to the buried pillarlike mass of Cripple Creek granite (see pp. 29-30) and are attributable to relative movement of the breccia along its contact.

The Midget-Moon Anchor vein zone consists of two sets of veins, one of which trends essentially northeastward and is intersected by veins of north-northeasterly trend. The most productive veins in the Anchoria-Leland-Geneva zone near the east wall of the embayment and east of the Midget-Moon Anchor zone also trend northeastward and are intersected by veins of north-northwesterly trend. The prevailing northeasterly trend of these veins conforms to the northeasterly trend of the contact south of the Midget shaft, which is also parallel to the long northeastwardtrending wall of the Unity embayment. The steplike recession of the contact along planes of northeasterly trend indicates that fissures of northeasterly trend form one of the two dominant sets 
of fissures along which the west wall of the basin was developed, and the vein fissures apparently owe their origin to recurrent movement along these and parallel fissures.

The principal vein in the Conundrun mine follows a basic dike, intruded on the upper levels along the contact between the breccia and granite, and fills what is clearly a fissure that has been reopened several times owing to recurrent movement along the contact.

The veins in the Abe Lincoln mine form a network in the granite close to the contact. In the upper levels the most prominent veins are of northwesterly or northeasterly trend, ${ }^{49}$ whereas on level 8 they are of easterly and northerly trend..$^{50}$ This network of vein fissures conforms to a conjugate pattern of fissures that is probably prevalent throughout the granitic rock. These conjugate fissures near the contact were reopened during late movements but, in the absence of any dominant plane of movement, apparently did not affect the breccia.

All the ore shoots in this part of the basin have been at relatively shallow depths, and production is not likely to be extended by exploration far below the present productive levels. Veins that have been followed any considerable distance down the dip beyond ore shoots have been found to be small and afford little evidence to encourage deep exploration. Although the sources of ore solutions were probably local, but deep-seated, structural conditions favorable to open fracturing and the formation of ore shoots apparently prevailed only relatively close to the surface. Accordingly further activity should be confined chiefly to systematic exploration of the upper levels of known vein zones and to a study of the contact to determine favorable structural features that might lead to the discovery of new vein zones. The fact that many of the vein zones correspond in distribution with major bends and jogs along the contact and conform in strike to the dominant fissures along which the basin was locally formed should serve as a guide in prospecting unexplored or inadequately explored parts of the contact.

From a study of the map and available evidence, two places along the west wall of the Moon Anchor embayment, the contact of north-northeasterly trend west of the Anaconda tunnel and the contact of northeasterly trend between the Index shaft and the Goodwill tunnel, show favorable structural relations and warrant further study and exploration. The Moon Anchor embayment be-

${ }^{4}$ Lindgren, Waldemar, and Ransome, F. L., op. cit., p. 276.

${ }^{\text {Bo }}$ Loughlin, G. F., and Koschmann, A. H., op. cit., p. 406. 
comes progressively wider toward the south by steplike recession to the southwest of segments of the west wall of the embayment. Apparently the recession was effected by subsidence of the segments along primary fissures of northeasterly trend. In places, late movement was localized along these primary fissure zones, which thus must be considered potential vein zones. A small ore body was found in the Moffat tunnel along the projected strike of the north-northeast stretch of contact west of the Anaconda tunnel. This encouraging showing indicates renewed movement and fissuring along this zone prior to ore deposition and, together with thorough and extensive fissuring along the northwest wall of the Unity embayment in both the granite and breccia, justifies systematic exploration along the trend of this zone.

The long contact of north-northeastward trend between the Index shaft and Goodwill tunnel represents the main fissure along which the Moon Anchor embayment was widened. The MidgetMoon Anchor vein zone falls along the projected strike of this zone and indicates that it also was reopened or formed prior to ore deposition. The relatively great length of this stretch of contact implies a zone of fissuring of proportional extent and is therefore considered a favorable prospect.

\section{VEIN ZONES IN THE NORTH SUB-BASIN}

The north sub-basin has been only a relatively minor producer; the ore shoots are relatively small, and most of the production has come from ore bodies within 750 feet of the present general surface. All parts of the sub-basin, however, have had some production, indicating that ore solutions were not wanting and that the controlling factor in the distribution of ore shoots, as in other parts of the district, was chiefly favorable structure. Most of the veins are in the breccia close to the contact and are parallel to the local structural features of the sub-basin, from which it is inferred that they occupy either tension fissures or fissures that mark the upward extensions of subsurface structural features. Those that coincide with the contact clearly occupy shear or fracture zones formed by relative movement of the breccia.

The veins in the North sub-basin fall into four groups-a western group, which includes the veins in the C. O. D., Gold King, and Mollie Kathleen mines and the Isis winze in the Sangre de Cristo tunnel; a northeastern group, which includes the small veins in the Hoosier mine; a southeastern group, which includes the veins in the Forest Queen, Jerry Johnson, Patti ROSa, and intervening mines; and a central group, which includes the veins 
in the Plymouth Rock, Ironclad, and Deerhorn mines. Included in the North sub-basin also is the Wild Horse vein zone in the granite along the east side of the granite island.

The more persistent veins and also the dikes in the C. O. D., Gold King, and the southern part of the Mollie Kathleen mines trend north-northeastward; in the Isis winze and Hoosier mine the more persistent and productive veins trend northwestward. The breccia-granite contact along the west side of the North subbasin follows a zigzag course in which sections of north-northeasterly trend alternate with sections of northwesterly trend; opposite the Hoosier mine the contact trends northwestward. The persistent veins thus show a parallelism with the local structural features of the basin, and the vein fissures no doubt originated through movement of the breccia along the contact or along subsurface features parallel to the contact.

The veins in the Forest Queen, Jerry Johnson, and Patti Rosa mines are mainly "flats," but some steep to vertical veins are also present. They either coincide with the contact or are chiefly in the breccia close to the contact. Their localization along the contact shows that the flats are in tension fissures produced by relative movement of the breccia mass, and the vertical veins occupy either the fissure along which the basin formed or parallel sheeted zones close by.

The Wild Horse vein zone at the surface approximately parallels in strike the contact between the granite and breccia. The most persistent vein, the Wild Horse, forms the central part of the zone. It is curved, striking north-northwestward north of the Wild Horse shaft and north-northeastward south of the shaft. To the south it has been traced for 1,000 feet, and it probably continues into the War Eagle mine, where the most persistent vein strikes northeastward and is either the continuation of the Wild Horse or is a parallel vein. It probably feathers out in the breccia on the southwest side of the island. To the northwest the Wild Horse vein has been traced continously almost to Midway, and the fissure zone evidently continues beyond and into the breccia, where, in the Solomon mine, a group of short veins in steplike arrangement and essentially parallel to the contact are found in line with the Wild Horse vein. The curved arrangement of this vein zone close to the eastern margin of the granite island and approximately parallel with the curved contact implies that it developed along or parallel to the dominant fissure zone that controlled the outline of the east side of the island.

The Plymouth Rock, Ironclad, and Deerhorn mines in the cen- 
tral part of the sub-basin have not been accessible, and no information more recent than that given by Lindgren and Ransome ${ }^{51}$ has been obtained on them. The breccia in these mines is shattered and thoroughly oxidized over a considerable area, and the oxidation descends at least 700 feet below the surface. Although veins are present, they are few and short and of diverse trends and dips. More commonly the breccia is cut by numerous seams and veinlets. One of the unusual features here is a mass of gypsum, probably hydrothermal in origin, which was cut in the Deerhorn shaft at a depth of 240 feet and which continues at least for about 300 feet to the bottom level. Its significance is described below. It is crystalline and contains grains of pyrite and a little disseminated fluorite. Small amounts of gold are present throughout the oxidized mass of breccia, which thus forms a large body of low-grade ore of unknown depth. The central position in the basin of this mineralized zone and the absence of any dominant trends of the veins preclude their. correlation with the structure of the basin; the general and intense shattering of the breccia suggests that the central part of the basin for unknown reasons collapsed and that the shattered zone may be deepseated.

Too little is known of the vein structure and the structure of the sub-basin to predict with assurance the downward continuity of any of its vein zones and sources of the ore solutions. The arrangement of most of the veins along or close to the contact suggests that the breccia, owing to settling, was more or less fractured and fissured along the margin, but only locally, where structural conditions were favorable, were open fissures formed. The ore solutions presumably rose along the deep-seated fractured ground along the contact, but only locally where it reached open fissures did effective mineralization occur. In other places either because the supply of ore solutions was too small or because the channels were too numerous and tight the solutions were too widely and ineffectively spread to form ore. Accordingly vein zones that essentially coincide with the contact afford the most favorable setting for downward continuity of productive ground.

On the basis of its structural setting and its production record, the Forest Queen-Jerry Johnson-Patti Rosa vein zone warrants exploration below its pxesent developed levels. This vein zone falls in line with the Empire-Victor zone and, together with the large number of productive veins in this part of the district adjoining the granite island, indicates general and widespread

o1 Lindgren, Waldemar, and Ransome, F. L., op. cit., pp. 284-285. 
movement just prior to ore deposition as well as the availability of ore solutions. Locally, also, small but encouraging ore shoots have been found on the bottom levels, and downward development may open up additional favorable ground.

Of unusual interest in this sub-basin is the local mass of gypsum that was cut in the Deerhorn shaft. Because of the single occurrence of such a mass. of gypsum in the district, its association with pyrite and fluorite, and the absence of gypsum as a primary mineral in the veins of the district, it is regarded ${ }^{52}$ as the product of hydrothermal activity. The thoroughly oxidized condition of the shattered breccia and the local depth of oxidation to at least 700 feet, to the level of the Chicago and Cripple Creek drainage tunnel, are also regarded as due to hydrothermal activity. Collectively these features suggest this to be a center of deepseated fissuring, which tapped the source of mineralizing solutions. As the oxidized breccia contains a small amount of gold throughout, it forms a large body of low-grade ore. Even though the deposit has not yet been a consistent or large producer, conditions justify exploration of the downward extension of this shattered mineralized zone.

Further surface prospecting in the North sub-basin should be confined to the more conspicuous fissures along which some of the irregular stretches of the contact were formed, especially on the west wall and near the Galena Hill embayment along the east wall. The west wall of the basin is locally marked by a series of sharp bends, the sides of which are approximatey parallel to some of the bends along the west wall of the South sub-basin. The presence of productive veins in the C. $O$. D. and Gold King mines and the Isis winze indicates movement and fissuring of the breccia prior to ore deposition. Although no productive veins have been found on the extension of some of these fissures along which the basin wall was formed, exploration here has been haphazard and not exhaustive, and systematic study and exploration may reveal mineralization along some of these fissure zones.

The Galena Hill embayment, one of the most conspicuous structures along the rim of the sub-basin, implies possible fissuring along its walls and extension thereof southwestward into the basin. Situated on the southeast side of the embayment in the granite is the Sunshine mine, which, though only a small producer, is of interest.53 The productive vein in the mine follows a phonolite dike of northwesterly trend and is thus at right angles

62 Lindgren, Waldemar, and Ransome, F. L., op. cit., pp. 220, 284-285.

${ }^{63}$ Lindgren, Waldemar, and Ransome, F. L., op. cit., pp. 281-282. 
to the longer axis of the embayment. The coincidence of the vein with the dike shows preore movement along established fissure zones, and, although the more recent fissuring is at an angle to the local basin-forming fissures, the possible fissure zones marked by the walls of the embayment should not be wholly ruled out as a prospect worthy of further attention.

\section{VEIN ZONES IN THE EAST SUB-BASIN}

Only two vein zones have been' found in the East sub-basinthe Cameron, near the northwest end of the basin, and the School Section, about 1,200 feet southeast of the Cameron. The Cameron zone trends northeastward, passes from the Whip and Glenn through the Pinnacle mine, and continues for about 300 feet southeast of the Cameron shaft on level 6 . It has a known length of about 1,200 feet. The most persistent and productive veins follow a set of phonolite dikes that trend about N. $40^{\circ}$ E.; however, south and southeast of the Cameron shaft on levels 6 and 7 the veins diverge from the dikes, curve to a N. $65^{\circ}$ E. course, and become discontinuous and irregular. This vein fissure zone is mostly in breccia, but on level 5 and lower levels it extends eastward into granite, and downward it coincides with the contact or follows a parallel fissure in the granite close to the contact. On levels 6 and 7 where followed farthest into the granite along the strike the vein zone terminates against phonolite dikes of northerly and northeasterly trends and has not been explored beyond this point. The local coincidence of this vein zone on the lower levels with the granite contact indicates that it is the upward extension of the master fissure along which the north wall was formed. Although there is a small variation in strike between the vein zone and the granite contact at the surface it is undoubtedly accounted for by recession of the basin wall through erosion during the late stages of subsidence.

The main ore shoot has been followed continuously to level 7 of the Cameron mine (altitude 9,114 feet). It pitches to the northeast toward the granite contact, and small shoots along irregular veins on the lower levels have been found in the granite. These relations suggest that the most likely source of the ore solutions was along the contact, probably near the point where the course of the basin wall changes from northeast to westnorthwest. Development on the bottom level was meager, and the contact was not as thoroughly explored along the projected pitch of the ore shoots as it deserves. Although the veins on the bottom 
level became unprofitable, assays are sufficiently encouraging to justify deeper exploration.

The School Section vein zone, explored only in the School Section mine, consists of four veins-the Sevey, Wilson, Kissel, and Malone, of northeasterly trend, and one short unnamed vein southwest of the shaft, of northwesterly trend. The vein zone follows a zone of latite-phonolite, phonolite, trachydolerite, and basaltic dikes, which probably extends across the sub-basin. The trachydolerite dike, known as the Sevey or "big basalt," extends southwestward through the Isabella (Empire-Lee) mine, ${ }^{54}$ where it is known as the Isabella dike. To the northeast the big basalt and a smaller basaltic dike in the School Section mine are correlated with two equivalent dikes exposed in the Gold Band mine, ${ }^{55}$ located on the northwest side of the Cameron embayment. On the basis of this correlation and the general alinement and parallelism of the dikes and veins with the northwest wall of the embayment, the School Section vein zone is regarded as the southwest extension of the master fissure along which the northwest wall of the embayment formed.

The Wilson and Kissel veins have been the most productive and have been explored to levels 6 and 8, respectively. The ore shoots found have been relatively short and occur both northeast and southwest of the shaft. Although no definite pitch of the ore shoots is shown, on levels 7 and 8 the only shoots found were northeast of the shaft, suggesting the source of the ore solutions to be northeast of the shaft. The apparent structural relation of the vein and dike fissure zone with the embayment and the suggested northeast pitch of the shoots indicate that the ore solutions, as along the Cameron zone, rose from a point near the contact, probably at the intersection of the north wall of the embayment and the east wall of the basin. Encouraging assays of veins near the basic dikes in the Gold Band mine afford additional evidence for this interpretation. The persistence of this fissure zone, as indicated by the successive intrusions of the dikes and later the formation of the veins, favors the downward continuity of the veins. Further exploration on the lower levels and below the present levels of the School Section mine, as well as at the surface along the northeast extension of this zone, seems warranted.

Present knowledge of the structure and geology of the East subbasin affords scant data regarding other favorable places for

54 Lindgren, Waldemar, and Ransome, F. L., op. cit., p. 91.

ss Loughlin, G. F., and Koschmann, A. H., op. cit., p. 385. 
prospecting. The smaller number of known productive veins and the relatively even rim of the basin imply that the East sub-basin is less favorably situated and constituted than other parts of the composite basin for the formation of extensive and productive vein zones. The localization of the two known vein zones in the northern part of the sub-basin and the small amount of exploration increase the difficulty of appraising the prospective value of other parts of the basin. However, based on the accordance in distribution of vein zones with jogs or bends along the contact, two areas as yet inadequately explored should receive further consideration-the sharp bend along the contact northeast of the Patti Rosa mine and the series of bends along the contact north of the Masterpiece embayment.

The eastward-trending contact northeast of the Patti Rosa mine is recessed about 800 feet northward along a northwardtrending fissure that falls in line with the projected strike of the buried granite ridge in the Isabella mine and the Empire-Victor vein zone. This suggests that the northward-trending fissure may be the northern counterpart of the shear zone along which the granite ridge was formed or is a parallel fissure in steplike arrangement. The large number of productive veins in this part of the district indicates general and widespread movement along favorably situated structural features, which formed fissures prior to ore deposition. The contact northeast of the Patti Rosa mine, therefore, deserves more attention than it has yet received.

The most favorable structural features for prospecting south of the School Section mine are the sharp bends north of the Masterpiece embayment. The zigzag course of the contact there, as in other parts of the basin, is probably of stectural origin and not an erosional feature of the wall. By analogy with other comparable structural features along the contact, which show accordance of vein zones with bends along the rim of the basin, this zone is entitled to some consideration. However, as this area is about 5.000 feet from any lanown produetivo roin zone and as present knowledge of the geology of this part of the basin is scant, it should be realized that any prospecting here is a decided gamble. 


\section{INDEX}

Anchoria-Leland-Geneva vein zone.

Beacon Hill vein zones

Biotite, occurrence

Cameron embayment, features

Cameron vein zone

Captain-Hidden Treasure veins

C. K. \& N. vein

C. O. D. mine, veins in

Carbonate Queen vein zone

Conundrum vein

Cresson blowout, features of veins in and near

Cresson-Rose $\mathrm{Nicol}$ vein zone-...._-_-_-_ 41-42

Cripple Creek basin, formation and geologic history -... 22-23, 25, 30-32 rocks of --structure of -

Deerhorn mine, veins in $53-54$

Dikes, occurrence $26,32,35$, $37,39,47,51,56,57, \mathrm{pl} .3$

Doctor-Jackpot vein

Eagle vein 36

East sub-basin, rocks of

vein zones in

56-58

East vein-Orpha May vein zone--- 38-39, 40-41

El Paso vein zone._-__-_-_ 45-46, 47-48, 49

Elkton vein zone 44-45

Empire-Victor vein zone_-____-_ 35-36

Findlay vein

Fluorite, occurrence -...-

Forest Queen mine; veins in______- 52, 53, 54

Front Range, rocks of

Galena Hill embayment, features

28,55

Geology of the district___._.

Gold, production of

Gold deposits, discovery of occurrence

Gold King mine, veins in

Gypsum, occurrence and significance

Henly fissure

Hoosier mine, veins in

Independence-Portland-Ajax vein zone

Index vein zone

Intrusive rocks, character and occurrence 25-26
Page

Ironclad mine, veins in

Isabella dike -_-_- 57

Isis winze, veins in

Jerry Johnson mine, veins in_-_-- $52,53,54$

Kissel vein

Loughlin, G. F., quoted__._. 43

Mable $M$. vein zone

Malone vein _-_-_._. 57

Mary McKinney-Morning Glory vein zone -

Masterpiece embayment, features_-_._- 28

Midget-Moon Anchor vein zone-_-_-_-_ 50, 52

Moffat tunnel, ore in 52

Mollie Kathleen mine, veins in_-__-_ 52,53

Moon Anchor embayment, vein zones in - 50-52

Nonvolcanic rocks, character-_-_--- 23-24, 31

North sub-basin, vein zones in-_-_-_-- 52-56

Northeast vein zone south of granite island

Ore, reserves of

Ore deposits, character and occurrence_- 32-35 See also particular mines, veins, and vein zones.

Paleozoic rocks, character and occurrence 21 Patti Rosa mine, veins in____._- 52, 53, 54 Plymouth Rock mine, veins in_____._53-54 Pointer vein _- 50 Pre-Cambrian rocks, occurrence_-_- 21, 28-30, 31 , pls. 3,4

Production from the district____- 21

Prospecting, suggestions for-_._. 34,36 , $37,38,40,41,42,43,44,45$, $49-50,51-52,54-55,56-57,58$

Purpose of the study

Pyrite, occurrence - 24, 48, 54

Pyroxene, occurrence

Raven fissure - 44

School Section vein zone-_. 57

Sedimentary rocks, character and occurrence -

Sevey vein _-

Sills, occurrence

Silver, production of

South sub-basin, vein zones in

Stocks, character and occurrence_____ 26, 37

Strong vein - 
Sunshine mine, veins in.

Volcanic rocks, chairacter and occurrence

Tertiary rocks, character and occurrence 21-22

Thompson fault

Waiter fissure

Vindicator-South Burns vein zone36-38 Wilson vein 